\author{
Gritsenko N. \\ Rud E.
}

\section{DEVELOPMENT OF AN EFFECTIVE PRODUCT QUALITY MANAGEMENT SYSTEM}

Об’єктом дослідження є управління якістю продукції. У ході дослідження використовувався метод аналізу при вивченні підходів до управління якістю виробленої продукції. В роботі розкрито теоретичні основи щодо управління якістю виробленої продукції. Показано, що для управління якістю виробленої продукиії варто встановити зв'язки між суб'єктами та об'єктами якості, їх зміни, використовуючи метод системного підходу. Цей метод продемонстрував, що для сталого економічного розвитку виробничого підприємства для початку треба дослідити структуру системи управління. Після ивого можна буде запропонувати вдосконалену систему управління, схематично зобразивши ї.

Запропоновані у роботі міжнародні стандарти дозволять виробнику бути конкурентноспроможними серед інших. Виробники, які прагнуть до експорту своєї продукиї, повинні впроваджувати у своє виробництво систему заходів, орієнтовану на високі вимоги до продукиії. Проте, перехід на сучасне обладнання має відбутися без жодного психологічного дискомфорту для працівників. Не варто забувати, що застосування системи управління якості на виробництві досить довготривалий та фінансово затратний. Процес перебудови підприємства має бути економічно обтрунтованим, оскільки власники повинні мати прибутки від виготовлення продукції. Тобто, впровадження системи управління якістю повинно бути економічно ефективною для виробничого підприємства. Використання інтегрованих систем контролю якості, в сучасну епоху інновацій, $\epsilon$ ознакою конкурентоспроможності підприємства.

В роботі отримано вдосконалену систему управління якістю продукиії. Це пов'язано з тим, що запропонована система має переваги, зокрема модернізацію матеріально-технічної бази та заохочення працівників, не лише за допомогою матеріальної винагороди, а й шляхом професійної кваліфікаціі.

Завдяки цьому забезпечується можливість отримання нових показників якості. У порівнянні з аналогічними застарілими методами якості запропонована модель забезпечує такі переваги, як впровадження інноваційних технологій та обладнання у виробництво, навчання сучасним технологіям працівників, що надасть змогу їм конкурувати на ринку праиі.

Ключові слова: системи управління, якість продукції, інтегровані системи контролю якості, конкурентоспроможність підприємств.

Received date: 18.06.2019

Accepted date: 04.07.2019

Published date: 30.10 .2019
Copyright (C) 2019, Gritsenko N., Rud E. This is an open access article under the CC BY license (http://creativecommons.org/licenses/by/4.0)

\section{Introduction}

There are a large number of enterprises in Ukraine that are trying to meet the needs of consumers. To do this, they need to produce high quality products. Improving production technologies will be the impetus for increasing the efficiency of the national economy. It should be noted that this process should be constant and controlled, since the level of quality is variable. The rapid development of scientific and technological progress, the latest production technologies, as well as the depreciation of the material and technical base of the enterprise encourage manufacturers to keep abreast of events for the introduction of innovative technologies in their production [1-3]. Each time step should be characterized by optimal product quality, while fully satisfying the needs of consumers, using the minimum cost of production [4, 5]. Thus, the object of research is quality management, therefore, the study of methods and technologies that will allow quality control is relevant. The aim of research is the theoretical justification and practically developed recommendations regarding product quality management in production at the time of Ukraine's European integration.

\section{Methods of research}

The following scientific methods are used:

- an analysis method when studying approaches to product quality management;

- a modeling method for obtaining research results.

\section{Research results and discussion}

The effectiveness of the quality management process is one of the key factors for economic growth. However, in order to integrate into the European Union and enter the international trade market, an enterprise must be competitive. Let's note that these processes require improvement. 
The rapid processes of integration of the Ukrainian economy require domestic manufacturers to introduce a system of quality standards. Given this, the problem of creating an effective product quality management system based on an integrative approach is extremely acute. In this regard, a promising task is to justify the structure of the product quality management system at the enterprise, to ensure that it fulfills its functional purpose [6]. The practice of integrated quality control systems by Ukrainian manufacturers enables more competitive enterprises to produce export-oriented products.

In order to get a clear control system, it is necessary to analyze the main subsystems that are interconnected from each other. Let's schematically depict it in Fig. 1.

As shown in Fig. 1, each subsystem should be responsible for the formation of labor resources, will be the result of quality products. Let's separately distinguish the following factors:

- control over the labor potential of the manufacturer;

- planning of quality indicators;

- stimulation of the quality of labor through the material support of workers, modern technical equipment of the production process on which the goods are manufactured, control and analysis of the quality of labor and products, assessment of labor quality.

It is worth noting that such a system is intertwined with other components of the overall enterprise management system - targeted, functional, organizational, moti- vational, social, economic, scientific, technical and technological.

To meet the requirements of the enterprise, international experts have developed standards called ISO 9000, which manufacturers must follow to meet the needs of consumers.

The requirements developed by the global community should be implemented by manufacturing enterprises in the most convenient way. This system is individual for each manufacturer, because it adapts to the specifics of the enterprise, its production capabilities, raw materials and internal characteristics of the activity.

The presence of this international certificate of evaluation of the quality system of a manufacturing enterprise gives a significant advantage in the search for markets. Investors prefer certified manufacturers, as they are confident in their products for sale.

According to experts, in the near future $95 \%$ of the contracts will be concluded with manufacturers who have passed the certification of ISO 9000 [7]. However, for a number of countries the lack of a certificate leads to a customs barrier or refusal to participate in tenders.

Voluntary certification successfully affects the reputation of the enterprise, strengthening its shares, and, consequently, increases the market value of the enterprise (according to the estimates of the international Det Norske Verites registry, by an average of $10 \%$ ). A survey of leaders of Western companies showed that voluntary certification of ISO 9000 in only $9 \%$ did not meet expectations $[8,9]$.

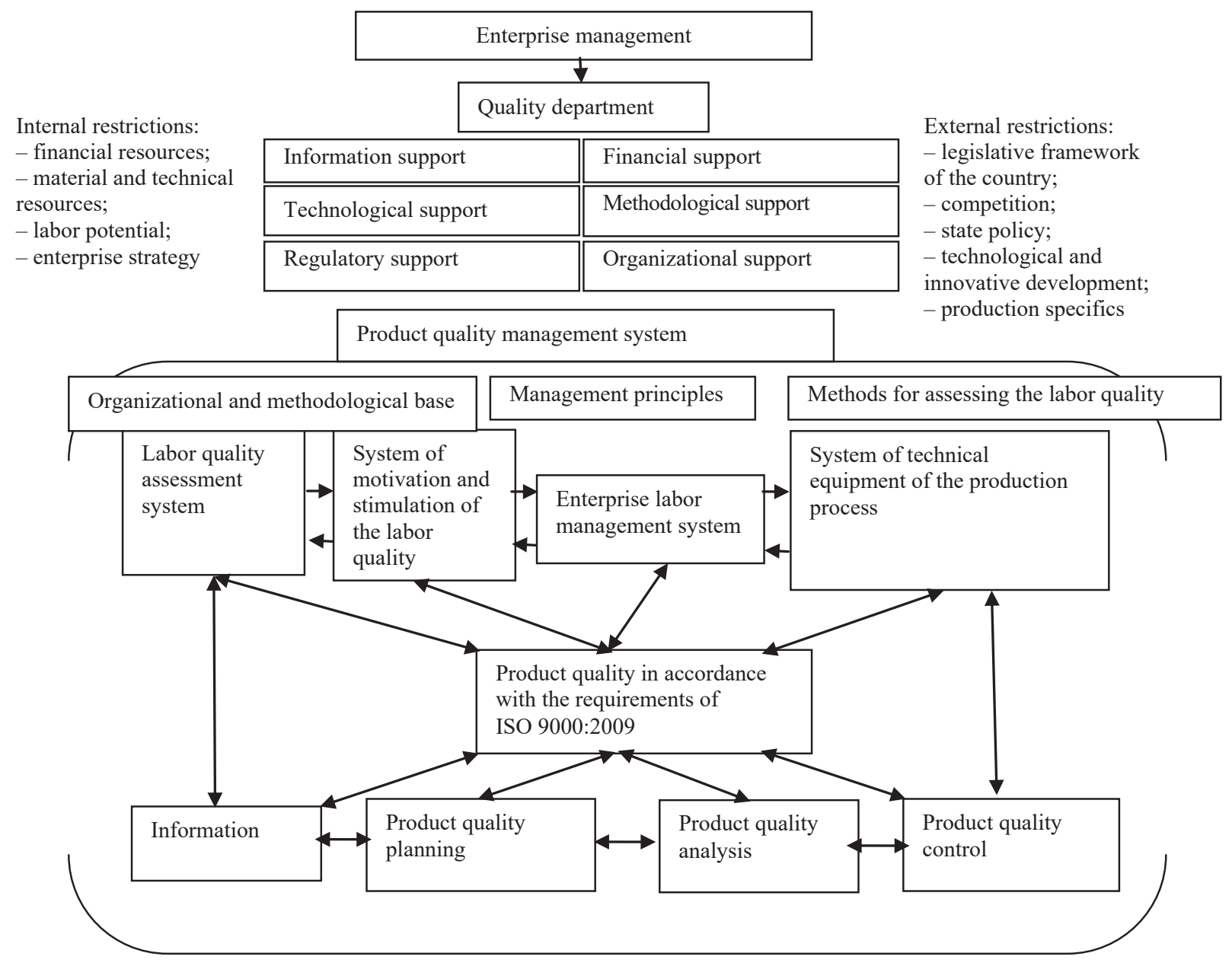

Fig. 1. Advanced product quality management system 
The implementation of a quality management system involves attracting labor resources to the process of improving the quality of goods, allowing employees to demonstrate their knowledge and skills in practice. The consequence of this will be a reduction in the cost of eliminating defects in production. These measures will allow the company to become transparent in relation to potential buyers. The ideology of the ISO 9000 series of standards system provides four areas of activity in which the quality of products is monitored at the intermediate stages of their life cycle, where each has its own characteristics. Before starting planning quality, let's outline the goals and requirements for the product.

Attention should be paid to suggestions for improving the quality characteristics, displaying information using graphs.

General quality management is carried out using operational methods, which include control at intermediate technological processes, their adjustment. Timely identification of any deviations from the established requirements for the quality of products and services is the main purpose of quality. Quality assurance should be planned and systematically monitored to ensure that the process or service meets established requirements.

Distinguish between internal quality assurance (the confidence of the organization's management in the conformity of products to the requirements and external (the creation of consumer confidence). ISO 9000 provides a certain number of procedures that organizations develop based on the specifics of their production.

It is also possible to talk about the model of quality assurance ISO 9001, which covers any type of entrepreneurial activity.

Most often, it is used by food industry companies, pharmaceutical companies and the IT sector.

To get a certificate, it is first necessary to decide on authoritative Western certification authorities, including:

1. Bureau Veritas Quality International (Great Britain) [10];

2. BSI (British Standard Institute) Group (Great Britain) $[11]$;

3. Lloyd's Register Quality Assurance Ltd (Great Britain) [12];

4. TUV CERT (Germany) [13];

5. Det Norske Veritas (Norway) [14];

6. Societe Generale de Surveillance (Switzerland) [15];

7. KEMA (Netherlands) [16].

When passing certification, a representative of the certification body visits the company for verification.

At the end of the audit, a protocol is drawn up with clearly indicated non-compliance with the requirements of ISO 9001. Usually, during the first stage of the passage, a lot of non-compliance is found, which must be eliminated within 1-4 months. After that, the certification itself is carried out. In the case of elimination of absolutely all violations, the company receives a certificate (a month is given for its design). The certificate is an official confirmation of the implementation of the quality system in production. Obtaining an ISO certificate opens up new prospects for the enterprise that will optimize production. Another key point is to maintain a positive image among investors, which will allow to receive any kind of order for the production of services or goods. At the same time, manufactured products will be sold at market prices.
In Ukraine there is another system ISO 9000:2015, which is used in the sugar industry. This certificate confirms that the quality management system for sugar production in accordance with the regulatory documents in force in Ukraine meets the requirements of DSTU ISO 9001:2015 (ISO 9001:2015 IDT) «Quality Management Systems. Requirements». At the moment, one sugar producer has passed ISO 9000:2015 certification. This is the Gnidavsky sugar factory (Rovantsy village, Volyn region, Ukraine). The company's management emphasizes that they will continue to implement innovative technologies in production in order to meet European quality requirements. However, what prevents other manufacturers from passing this examination? First of all, the absence for a long time in the production of innovative technologies. To do this, it is necessary to re-equip the technological stations at intermediate stages of production. But for this, business owners must invest a large amount of money in production. However, not all owners are ready for this. In conditions of low sugar prices, they are forced to save every penny in order to continue to produce sugar products. Therefore, it is economically unprofitable for them to update the material and technical base of the enterprise. However, the use of this management system is a sign of improving production capacities.

Given the above, let's note that modern global processes require manufacturing enterprises to change approaches to quality control. To do this, it is necessary to pay attention to international standards that see integrated quality management processes. In Ukrainian industry, only the leading enterprises have switched to certified quality control systems. The use of an integrated system in production is strategically effective for the further economic development of the enterprise. However, most industrial enterprises in Ukraine do not meet international standards generally recognized in the world. The global economic crisis, under the influence of which enterprises fell, forced enterprises to abandon the improvement of quality control. Since, the expansion of export opportunities and sustainable economic development should be carried out taking into account economic, environmental, technological, social and other indicators.

Let's recommend that choosing a phased strategy for the restructuring of the enterprise for the best management strategy, gradually introducing international standards for quality systems. The main basis for the implementation of the integrated system is to check the quality of products in the ISO 9000 series system. After that, attention should be paid to the environmental management system (ISO 14000) and occupational safety system (OHSAS 18001), at the third stage - to the social responsibility system (SA 8000). At the same time, it is necessary to create better working conditions and hiring, manage labor potential, invest in the knowledge and skills of workers in accordance with the standards of social responsibility management (SA 8000). This improved system will be an effective working structure, because it takes into account effective technical and managerial methods for obtaining labor results, methods of interaction between people and technology, as well as information in order to meet the needs of consumers. The development of such a plan should involve the entire team, focused on production ethics and production culture [17]. It is worth noting that management should be economically justified, since it must clearly know the positive and negative consequences of introducing the system in production. The introduction 
of innovative technologies should be accompanied by qualified training of workers who must overcome barriers to a quick transition to automated processes. A mandatory requirement is that modernization should be combined with the organizational structure and management strategies.

\section{Conclusions}

In the course of the research, the authors made recommendations, which consist in the fact that for the best management strategy it is necessary to choose a phased restructuring of the enterprise, gradually introducing international standards of the quality system.

Economically sound management is useful to management, which should clearly know the positive and negative consequences of implementing a quality system in production.

\section{References}

1. Hrytsenko, N. V., Yakovenko, V. H. (2014). Formuvannia hnuchkoi modeli upravlinnia personalom na zaliznychnomu transporti. Naukovyi visnyk Donbaskoi derzhavnoi mashynobudivnoi akademii, 2 (14E), 144-148.

2. Kostiuk, O. D. (2006). Kontseptsii suchasnykh system upravlinnia yakistiu produktsii ta posluh. Naukovi dopovidi NAU, 2 (3). Available at: http://base.dnsgb.com.ua/files/journal/ Naukovi-dopovidi-NAU/2006-2/kostuk.pdf

3. Momot, O. I. (2014). Mozhlyvosti vykorystannia mizhnarodnykh standartiv dlia pobudovy intehrovanykh system menedzhmentu. Visnyk Kyizskoho natsionalnoho universytetu tekhnolohii ta dyzainu, 5 (37), 133-138.

4. Midor, K., Žarnovský, J. (2016). Innovative Use of Quality Management Methods for Product Improvement. Management Systems in Production Engineering, 24 (4), 264-267. doi: http:// doi.org/10.2478/mspe-08-04-2016
5. Daly, T., Kowalewski, M. (Ed.) (1994). Where Real Product Quality Starts. Quality and Statistics: Total Quality Management. West Conshohocken: ASTM International, 43-52. doi: http:// doi.org/10.1520/stp13191s

6. Fedorov, H. Ye.; Fedorov, H. Ye. (Ed.) (2013). Kontrol yakosti produktsii v mashynobuduvanni. Kyiv: Kramatorsk, 332.

7. Varianychenko, O. V., Karasova, H. V. (2009). Standarty ISO 9000: Yakist produktsii ta osnova doviry mizh vyrobnykom ta spozhyvachem. Ekonomichnyi visnyk NHU, 1, 115-122. Available at: http://ir.nmu.org.ua/bitstream/handle/123456789/460/2009 1 p115-122.pdf? sequence $=1$ \&isAllowed $=y$

8. Total Quality Management (2017). Butterworth-Heinemann: Elsevier, 580. doi: http://doi.org/10.1016/c2016-0-00426-6

9. Yevropeiskyi fond upravlinnia yakistiu (2003). Yevropeiska yakist, 4, 5-8.

10. Bureau Veritas Certification. Available at: https://certification. bureauveritas.com/

11. BSI Group. Available at: https://www.bsigroup.com/

12. Lloyd's Register Group. Available at: https://www.lr.org/

13. $T \ddot{U} V S \ddot{U} D$. Available at: https://tuv-cert.de/

14. Det Norske Veritas group. Available at: https://www.dnvgl.com/

15. SGS. Available at: https://www.sgs.com/

16. KEMA Laboratories. Available at: https://www.dnvgl.com/energy/ laboratories/index.html

17. Orlov, P. A. (2013). Vprovadzhennia system upravlinnia yakistiu: stan, problemy, perspektyvy. Standartyzatsiia, sertyfikatsiia, yakist, 6, 59-63.

Gritsenko Nataly, PhD, Associate Professor, Department of Economics, Business and Personnel Management for Transport, Ukrainian State Academy of Railway Transport, Kharkiv, Ukraine, ORCID: http:// orcid.org/0000-0002-2901-1411, e-mail: gritsenkonatal@gmail.com

Rud Elizaveta, Department of Entrepreneurship and Tourism, Kharkiv Cooperative Trade and Economic College, Ukraine, ORCID: http:// orcid.org/0000-0002-7495-542X, e-mail: elizavetarud6@gmail.com 